\title{
Forestry Research Advisory Council of Canada Annual Report for 1988
}

\author{
Summary
}

This report covers the 1988 calendar year. During the year, the Forestry Research Advisory Council of Canada focussed on several issues, but three stand out.

Firstly, it became clear to the Council that there is an emerging consensus about the importance of forestry research in Canada and the need to involve industry more in the planning and executing of research as increasing demands are made on the resource and environmental concerns grow.

Secondly, the Canadian Council of Forest Ministers convened a national forestry forum in Edmonton entitled "Innovation and Technology: Science in the Forestry Sector." Its 13 recommendations, endorsed by the Canadian Council of Forest Ministers, will be carefully studied by all forestry research organizations in Canada.

Finally, representatives of the provincial and territorial forestry research advisory groups completed a plan for the preparation of a national overview and synthesis of forest research priorities and views in 1989 .

Council wishes to make the following recommendations to Forestry Canada:

1. Forestry Canada should continue to provide a very brief annual, year-end communication to FRACC, providing in point form, information on actions taken on FRACC recommendations made at the close of the previous year.

2. Considering the broadly based support for the action plan stemming from the 1988 national forestry research forum in Edmonton, Forestry Canada must ensure that the recommendations are implemented in the Forestry Canada program.

3. Forestry Canada should encourage and strengthen forest resources oriented activities of the Forest Sector Advisory Council and by using research advisory structures increase that Council's understanding of the importance of forest resources research.

4. Forestry Canada should ensure that in negotiating the next generation of forestry agreements, due attention is paid to planning and executing the very important research components so that they are clearly recognized and planned and managed to ensure the information produced is readily available across the country.

5. Forestry Canada should intensify its efforts to disseminate research findings from all sources through joint sponsorship of seminars and workshops.

6. Council recommends that Forestry Canada continue to seek innovative means to foster an enhanced and sustained input to forest management research by the forest-based industry.

7. Forestry Canada should encourage the use of industry "assistance in kind" by working with Revenue Canada to ensure that industry participants in such programs are fully eligible for favourable tax treatment for such research.
8. Forestry Canada should try to mitigate the potential negative effects of the Canadian Environmental Protection Act and its regulations on forest research.

9. Forestry Canada must continue to press the federal Treasury Board for a significant upward adjustment in its base funding for the operation of its research program. Funding from Forest Resource Development Agreements should be considered incremental to the base funding of the Forestry Canada program.

10. Council agrees with the general tenor and thrust of the recently approved Forest Insect and Disease Survey Strategic Plan that provides for a shift away from routine surveys to research, but recommends that Forestry Canada maintain and enhance its leadership in conducting workshops and technology transfer seminars on specific pest problems.

11. Forestry Canada should expedite completion of its planning document for biotechnology research. Forestry Canada must be able to collaborate actively in this important research area.

12. Forestry Canada should complete and widely distribute its strategic plan for spruce budworm research as soon as possible.

13. Forestry Canada should make greater use of economics criteria in research evaluation and planning, and developing improved methods for analysing forest land management options.

In 1989, Council will organize its work under three headings. Concerning research and development, the essential part of its mandate, Council will 1. focus on a review of current Forestry Canada programs; 2 . continue to investigate means for increasing industry's involvement in research; 3. study and recommend how the research inventory work initiated by Dr. Kayll can be used and regularly updated; 4 . continue to study Forestry Canada operating and maintenance funding and make recommendations as appropriate.

On policy and planning, Council will 1. review and advise Forestry Canada on the CCFM research forum implementation report; 2. review and comment on future plans for Forestry Canada regarding organization, legislation, facilities, research program and the research planning process.

Regarding the research advisory process, Council will 1. establish closer communications with the Forest Sector Advisory Council and other national advisory groups, including those for the Petawawa National Forestry Institute and the Forest Pest Management Institute of Forestry Canada, the Forest Engineering Research Institute of Canada, Forintek and the Pulp and Paper Research Institute of Canada; 2. continue to work with the provincial and territorial forest research advisory bodies to provide a national overview of priorities and viewpoints for the Canadian Council of Forest Ministers. 


\section{Introduction}

The Forest Research Advisory Council of Canada (FRACC) was created in 1983 to advise Forestry Canada (formerly the Canadian Forestry Service) on forestry research priorities and policies at the national level. In 1987, its role was expanded to prepare an annual national overview of research priorities and concerns to the Canadian Council of Forest Ministers (CCFM)

This report covers the calendar year 1988. During the year, the Council held three meetings (see Appendix II) and provided comments and advice to the deputy minister, Forestry Canada, on several research-related issues. These comments are captured in the recommendations in this report.

\section{Importance of Forestry Research - An Emerging Consensus}

During 1988, Council noted an increasing awareness of the importance of forestry research in Canada. The interest shown in the 1988 Edmonton forum entitled "Innovation and technology: Science in the Forestry Sector" and sponsored by the Canadian Council of Forest Ministers indicates this heightened awareness. It is widely recognized now in all components of the forestry sector that Canada is in an important transition in the management of her forest resources. We are approaching the limits of our natural forest resource and are moving rapidly into a period of much more intensive management. At the same time we are delegating increasing responsibility for forest management to the forest industry through variations on the forest management agreement concept. In addition, it is clear that more and more demands are being made on the forest resource itself to produce more timber and more non-timber benefits in a climate of increasing concern about environmental matters.

The result of these trends is that forest managers both in government and industry are under mounting pressure to increase timber yields, produce more non-timber values such as wildife and recreation opportunities and to do it all in ways that are environmentally sound and sustainable in the long term. Although much progress has been made through research on forest protection, forest productivity and forest utilization with resultant changes in forest policies, there is still much to be learned to improve the efficiency and effectiveness of forest resource management. For example, more information is needed on the quality of wood from the intensively cultured "new forest" and its suitability for manufacturing various forest products. When practitioners start demanding more research and start participating in formulating research questions, there is a marked "climate change" in the world of forest research and its application. Council is convinced that this change is well under way. The challenge will be to convince policy and decision leaders that the change is occurring and that increased support for research will pay off both financially and in public acceptance of forest management in the future.

Council had earlier stressed the importance of Forestry Canada having a well-formulated strategic plan for research and was pleased and encouraged with the appearance of the plan entitled "Focus on Research" in late 1987. Council has used this document in 1988 as a useful framework for examining Forestry Canada programs and notes with satisfaction that the plan was reprinted in 1988 and more widely distributed. Council strongly supports the point made in the plan that "progress will require more explicit government and public recognition of the essential role of research in forest sector viability; a greater and more sustained commitment to forestry research by industry; and further strengthening of technology transfer, advisory activities and research management co-ordination mechanisms both within CFS and between CFS and its constituencies."

\section{Current Terms of Reference for FRACC}

Council's terms of reference were reviewed during 1988 and changes made to provide for FRACC's new mandate from the Canadian Council of Forest Ministers to provide an annual review and synthesis of the priorities and concerns identified by the provincial and territorial forestry research advisory bodies. The naming of a vice-chairman was provided for and wording changes were made as required for clarity in accordance with the new full department status of the federal forestry program (see Appendix III).

\section{Actions Stemming From Council's 1987 Report}

Council made nine recommendations to the then Canadian Forestry Service in its 1987 report. In its responses to these recommendations, as published in the 1987 report, the Service accepted, welcomed or agreed to all of them. The following is a list of actions that Forestry Canada agreed to take:

1. A periodic review of forest sector research expenditures.

2. Address the question of the adequacy of current levels of forestry research expenditures.

3. Pursue the initiative to create research advisory bodies in collaboration with provinces and territories.

4. Periodically revise the strategic plan for research and distribute it widely.

5. Concentrate on communication with the public to increase awareness of the benefits of appropriate pesticides.

6. Stress the importance of a strong federal government forest management research program to other federal agencies.

7. Discuss with Ministry of State for Science and Technology the possibility of reducing the heavy administrative paper burden resulting from recent new policies on science.

8. Review the issue of research and taxation.

9. Develop a specific strategy for biotechnology research.

This is an impressive list and progress has been made on many items. Forestry Canada has provided a summary of actions taken on the 1987 recommendations which is attached as Appendix IV.

Recommendation 1 - Forestry Canada should continue to provide a very brief annual, year-end communication to FRACC providing, in point form, information on actions taken on FRACC recommendations made at the previous year's end.

\section{National Forestry Forum on Innovation and Technology}

In February 1988, at Edmonton, Alberta, the Canadian Council of Forest Ministers sponsored a national forestry 
forum on research and development entitled "Innovation and Technology: Science in the Forestry Sector." The result of the forum was 13 recommendations giving direction for an enlarged and more sharply focussed forestry research program in Canada. An implementation committee, whose report was accepted by the Canadian Council of Forest Ministers in September 1988, expects to release its report in early 1989.

Council is strongly supportive of the process followed in organizing this forum and of its 13 recommendations and has so advised the chairperson of the Canadian Council of Forest Ministers. Council is anxious to have these recommendations implemented.

Recommendation 2 - Considering the broadly based support for the action plan stemming from the 1988 national forest research forum in Edmonton, Forestry Canada must ensure that the recommendations are implemented in the Forestry Canada program.

\section{Research Advisory Structures}

In 1987, the Canadian Council of Forest Ministers responded positively to the recommendation that FRACC undertake an annual review and synthesis of the viewpoints and priorities of the senior forest research advisory body in each province and territory. During 1988, a process to provide the national overview for the CCFM was designed in cooperation with the various provincial and territorial forestry research advisory bodies. A meeting between the members of the Council and representatives of the provincial and territorial bodies was convened in Ottawa on October 19,1988 . Chaired by FRACC chairperson Jack Wright, this meeting was attended by representatives from all ten provinces and resulted in a procedure and schedule agreeable to all present. Unfortunately, representatives from the two Territories could not attend but they have been kept fully informed. A review document will be ready for presentation to the Canadian Council of Forest Ministers at its fall meeting in 1989.

Council briefly reviewed the situation pertaining to the Forest Sector Advisory Council of Canada (FSAC) which advises federal ministers on forestry issues in general. FRACC believes that the forest manufacturing sector of FSAC is functioning well but that the forest resources side is not receiving similar attention. It is recognized that some members of FSAC are working hard to correct this situation.

Recommendation 3 - Forestry Canada should encourage and strengthen forest resources oriented activities of the Forest Sector Advisory Council and by using research advisory structures increase the Council's understanding of the importance of forest resources research.

\section{Forest Resource Development Agreements}

Federal-Provincial Forest Resource Development Agreements (FRDAs) have been a significant source of research funding in recent years. Council noted that the research support component of the agreements is not well recognized and has been difficult to trace, monitor and coordinate nationally.

Council believes the Forest Resource Development Agreements are very important in improving forest management. The research components are of particular concern and require closer attention in planning the next generation of agreements.
Recommendation 4 - Forestry Canada should ensure that in negotiating the next generation of forestry agreements, due attention is paid to planning and executing the very important research components so that they are clearly recognized and planned and managed to ensure that the information produced is readily available across the country.

\section{Industry Involvement in Forest Management Research}

At the Council meeting held in Ottawa in October 1987 , the deputy minister asked Council to advise him how the forest industry could play a more active role in forest management research. This topic was discussed by Council in 1988 and has been the subject of correspondence with Forestry Canada. As noted earlier, it is clear that industry's increasing responsibilities in forest management and the pressure to manage the forest with minimum negative impact on the environment is making industry much more conscious of the need for more research.

Council is convinced that much information on how individual agencies and companies have solved specific problems does not get circulated or used elsewhere. The Canadian Pulp and Paper Association is to be commended for its expanding interest in publications and seminars, which will help solve this problem. Similarly, the new emphasis on provincial forestry research advisory bodies and the seminars and workshops sponsored by these bodies will be useful in demonstrating the results obtained in many local situations. Furthermore, these bodies will provide useful avenues for channelling industry viewpoints on research priorities to the research agencies. The importance of responses to the research agencies should also be stressed.

Recommendation 5 - Forestry Canada should intensify its efforts to disseminate research findings from all sources through joint sponsorship of seminars and workshops.

Council believes that it is very important to get industry senior managers involved and interested in research. Experience has shown that this is absolutely necessary if industry is to participate effectively in the guiding of research and even more necessary if it is to effectively use the results.

Recommendation 6 - Council recommends that Forestry Canada continue to seek innovative means to foster an enhanced and sustained input to forest management research by the forest-based industry.

Industry has contributed significantly to many forest management research projects through provision of "assistance in kind." These inputs of work crews, plot locations, transportation, etc., have often determined whether or not a project could be completed. Industry forestry staff sometimes has not been fully aware of the tax provisions for research, and recognition of these inputs for income tax purposes has not always been obtained, so some firms have hesitated to participate. Council recommended action on this tax question last year and arranged for a presentation by a senior representative of Revenue Canada on this subject at its joint meeting with the chairpersons of provincial advisory bodies in October 1988. The presentation was very well received.

Recommendation 7 - Forestry Canada should encourage the use of industry "assistance in kind" by working with Revenue Canada to ensure that industry participants in such programs are fully eligible for favourable tax treatment for such research. 


\section{Catalogue of Forest Science Activities}

In 1986, council requested Forestry Canada to set up a readily revisable national catalogue of forest and forestrelated research to assist in determining forest research needs and priorities. Dr. A.J. Kayll of Lakehead University undertook this work in Ottawa during 1987-88 while on sabbatical leave from Lakehead University.

A computerized catalogue of some 1200 projects with base year 1985-86 was completed in 1988. Computer disks of the catalogue have been distributed to Council members for evaluation. This assessment should be completed in early 1989 and Council will be making recommendation on the future disposition of this project at that time.

\section{Canadian Environmental Protection Act}

Bill C74 was introduced in June 1987 and passed in mid-1988. The overall intent is to provide regulations for the protection of the environment where other legislation does not apply. Part 2 of the act dealing with toxic substances could strongly influence forestry research. Toxicity is broadly defined, for example, in terms of potential "harmful effects" on the environment or by affecting "important biological processes." The burden of proof that a substance is not toxic rests with the agency that wishes to use it in the environment. Plans to release substances into the environment must be reported to Environment Canada a year before the planned release. Draft regulations have been soundly criticized by the research community and Environment Canada is reworking them.

Council believes that forest research on such diverse topics as genetically engineered trees, new forest products, biological control of pests, use of naturally occurring mycorrhiza, forest fertilization and the use of forest fire retardants could be seriously hampered unless the regulations and their application are very carefully thought out.

Recommendation 8 - Forestry Canada should try to mitigate the potential negative effects of the Canadian Environmental Protection Act and its regulations on forest research.

\section{Forestry Canada Budget Trends}

Forestry Canada's operating and maintenance funds have been diminishing seriously since the early $1980 \mathrm{~s}$. In $1983-84$, $\$ 22.4$ million was budgetted for this purpose. This was reduced to $\$ 18.5$ million in $1987-88$ but the real reduction in purchasing power has been much greater. In terms of $1983-84$ dollars, the $1987-88$ operating budget is only about $\$ 15.7$ million (assuming inflation at $4 \%$ for $1984-88$ ). When one considers that the inflation index for science is much higher than the consumer price index because of the increasing sophistication and complexity of modern scientific instrumentation and techniques, the true dimensions of this crisis situation begin to emerge. Council noted that Forestry Canada has become very dependent on the FRDAs for operating funds for its ongoing research program. Some of the Forestry Canada centres would scarcely be able to operate without this short-term funding.

Recommendation 9 - Forestry Canada must continue to press the federal Treasury Board for a significant upward adjustment in its base funding for the operation of its research program. Funding from Forest Resource Development Agreements should be considered incremental to the base funding of the Forestry Canada program.

\section{Forest Insect and Disease Survey}

Council reviewed the Forest Insect and Disease Survey (FIDS) Strategic Plan as prepared by Forestry Canada. The proposal is to reduce or phase out work on routine pest detection as provincial agencies become able to assume responsibility for this work. The FIDS will thus be able to focus more effort on developing new techniques for pest surveys, pest outbreak forecasting, collating national forest pest statistics and fulfilling the requirements of the Federal Plant Quarantine Act. The overall intent is to maintain the Forestry Canada total commitment to pest management surveys and research.

Recommendation 10 - Council agrees with the general tenor and thrust of the recently approved Forest Insect and Disease Survey Strategic Plan that provides for a shift away from routine surveys to research, but recommends that Forestry Canada maintain and enhance its leadership in conducting workshops and technology transfer seminars on specific pest problems.

\section{Bioenergy Research}

Council received Forestry Canada's Strategic Plan for Bioenergy Research and agrees with the plan to maintain funding at close to the $1987-88$ level of $\$ 900000$ with program emphasis on increasing biomass productivity and assessing the environmental impact of intensive forest energy culture. The continued and intensified technology transfer efforts are also applauded.

\section{Biotechnology Research}

Forestry Canada, during 1988, has been preparing a strategic plan for its biotechnology research program. This process is not yet complete, although a good deal of very useful analysis has been done on this very important and expensive research field. A task force to review the field has completed its work and reported that low operating budgets and scarcity of trained personnel are serious constraints. Four of the strategic areas for research have been identified that are particularly germane to Forestry Canada capabilities: 1. plant cell and tissue culture, 2. plant pathogens/control, 3. insect pathogens/control, and 4. nitrogen fixation and mycorrhiza.

Recommendation 11 - Forestry Canada should expedite completion of its planning document for biotechnology research. Forestry Canada must be able to collaborate actively in this important research area.

\section{Spruce Budworm Research}

Council reviewed two Forestry Canada working documents. The first, authored by five scientists, was designed as a background paper for preparation of the strategic plan. The need to study low density populations, devise further control alternatives to chemicals and to improve transfer of research results into practise was emphasized. The second document prepared by D.A. MacLean is entitled "CFS Spruce Budworm Program Assessment Report." The recommendations made in this report, while differing in some detail, follow the three main areas of emphasis noted previously. Council agrees that these areas require attention but urges that the strategic plan be completed.

Recommendation 12 - Forestry Canada should complete and widely distribute its strategic plan for spruce budworm research as soon as possible. 


\section{Economic Studies in Forest Science}

In its 1987 report, Council commented on the program plan for economics that had been prepared by the CFS and urged that more consideration be given to economic analysis of forest science programs, although a formal recommendation was not made to that effect.

Council noted at its June meeting that in Forestry Canada there seem to be three types of economic work: a) work in support of general policy analysis; b) economics input into forestry research, for example, evaluation of potential research payoffs; and c) economics methodology research. Council still believes that the Forestry Canada economics program is too heavily oriented towards general policy analysis and that too little is being done in support of science programs and in methodology, particularly methodology for assessing land management options.

Recommendation 13 - Forestry Canada should make greater use of economics criteria in research evaluation and planning, and in developing improved methods for analysing forest land management options.

\section{Plan of Action for 1989}

Council will organize its work for 1989 under three headings as follows:

\section{Research and Development}

1) In responding to the essential part of its mandate, Council will focus on a review of current Forestry Canada programs as they relate to the document "Focus on Research."
2) Continue to investigate means for increasing industry's involvement in research.

3) Study and recommend how the research inventory work initiated by Dr. Kayll can be used and regularly updated.

4) Continue to study trends in Forestry Canada operating and maintenance funding and make appropriate recommendations.

\section{Policy and Planning}

1) Review and advise Forestry Canada on the CCFM Edmonton research forum implementation report.

2) Review and comment on plans for the future development of Forestry Canada regarding organization, legislation, facilities, research program and the research planning process.

\section{The Research Advisory Process}

1) Establish closer communications with the Forest Sector Advisory Council and other national advisory groups including those for the Petawawa National Forestry Institute, the Forest Pest Management Institute, FERIC, Forintek and Paprican.

2) Continue to work with the provincial and territorial forest research advisory bodies to provide a national overview of research priorities and viewpoints as required for the Canadian Council of Forest Ministers.

\section{Appendix I \\ FRACC Membership for 1988}

\section{Provincial Representation}

Mr. Kenneth A. Armson

Provincial Forester

Ministry of Natural Resources

Room 6520, Whitney Block

99 Wellesley Street West

Queen's Park

Toronto, Ontario

M7A 1W3

Mr. John Cuthbert, Chief Forester

Government of British Columbia

595 Pandora Avenue

Victoria, British Columbia

V8W 3E7

\author{
M. Claude Godbout, Directeur \\ Direction de recherche et de \\ développement \\ Ministère de l'énergie et \\ des ressources \\ Complexe scientifique \\ 2700, rue Einstein \\ Ste-Foy (Québec) \\ G1R 3W8
}

\section{Mr. Robert Mercer}

Director of Forest Management

Department of Forest Resources $\&$ Lands

Box 2006

Corner Brook, Newfoundland

A2H $6 J 8$
Tel: 416-963-2095

Telex: 06219701 MNR CC TOR

Facsimile: 965-6336

Tel: 604-387-1296

Telex: 049-7269

Facsimile: $387-6267$

Tel: 418-643-7994

Telex: 051-31589 SDBCS-QBC

Facsimile: $643-2165$

Tel: 709-637-2344

Telex: 016-44109 FORSERV SNF

Facsimile: $637-2403$
Mr. D. Rannard, Director

Forestry Branch

Department of Natural Resources

300-530 Kenaston Blvd.

Winnipeg, Manitoba

R3N 1 Z4

\section{Industrial Representation}

Mr. B.W. Burgess

Hillcrest Road

R.R.\#3

Brockville, Ontario

K6V 5T3

Monsieur Jean Paquet, chef forestier

Domaine forestier

Consolidated Bathurst Inc.

800 , boul. Dorchester Ouest

Montréal (Québec)

H3B 1 Y 9

Mr. Hollis Routledge

Woodland Manager

STORA Forest Industries

Box 59

Port Hawkesbury, Nova Scotia

BOE 2VO
Tel: 204-945-7998

Facsimile:

204-489-1360
Tel: 613-345-2285

416-488-5262

Tel: $514-875-2160$

Telex: 0525165

Facsimile:

514-875-6284 
Mr. Jack Toovey, R.P.F.

General Manager Timberlands and Forestry

B.C. Forest Products Ltd.

1050 West Pender Street

Vancouver, British Columbia

V6E $2 \times 3$

\section{Mr. Jack Wright, Forestry} Consultant

Box 2363

Hinton, Alberta

TOE 1CO

\section{University Representation}

Monsieur Gilles Frisque, directeur

Centre multi-régional de

recherche en foresterie

Université du Québec

$3^{\mathrm{e}}$ étage

2875 , boulevard Laurier

Sainte-Foy (Québec)

G1V 2M3

Dr. Peter Murphy

Associate Dean of Forestry

Faculty of Agriculture and Forestry

214 Agriculture/Forestry Building
Tel: 604-665-3821

Facsimile: 604-665-3816

Tel: 403-865-2729

Telex: 0372288 STREGISALT HTN

Facsimile: 403-865-8129

Tel: 418-657-3551

Telex: 05131623

Facsimile: 657-3551

Tel: 403-492-4933

University of Alberta

Edmonton, Alberta

T6G 2P5

\section{Ex-officio}

Mr. Gerald Lapointe

Woodlands Section

Canadian Pulp and Paper

Association

1155 Metcalfe Street

23rd Floor

Montreal, Quebec

H3B 2X7

Dr. F.C. Pollett

Director General

Forest Science Directorate

Forestry Canada

Ottawa, Ontario

K1A $1 \mathrm{G} 5$

\section{Executive Secretary}

Dr. R.J. Bourchier

R.R.\#1

P.O. Box 255

Cantley, Quebec

JOX 1 LO
Tel: 514-866-6621

Facsimile:

514-866-3035

Tel: 819-997-1107

Facsimile:

819-997-8697

Tel: 819-827-0903

\section{Appendix II \\ FRACC Meetings 1983-1988}
1. Toronto
2. Montreal
3. Vancouver
4. Ottawa
5. Fredericton
6. Edmonton
7. Sault Ste. Marie
8. Victoria
9. Quebec
10. Ottawa
11. Vancouver
12. Quebec
13. Ottawa
14. Toronto
15. Ottawa
16. Hull

\author{
August 12-13, 1986 \\ November 13-14, 1986 \\ March 11-12, 1987 \\ June 11-12, 1987 \\ October 20-21, 1987 \\ February 24-25, 1988 \\ June $21-22,1988$ \\ October 18,1988
}

\section{Appendix III \\ FRACC Current Terms of Reference}

The Forestry Research Advisory Council of Canada provides the Deputy Minister, CFS, with sound, independent information and advice concerning the state of forestry research in Canada, particularly as regards the research programs of the Canadian Forestry Service.

The goal of the Council is to promote effective forest protection and management on a scientific basis in order to improve Canada's forest resources, particularly the economic wood supply, in relation to present and future needs.

To this end, the Council provides a national focus for forestry research coordination, identifies broad research needs and priorities and reviews research activities to obtain a balanced response to national and regional needs.

\section{Functions}

More specifically, the Council's functions are to:

1. Review and participate in the development of the Canadian Forestry Service research policies and strategic plans.
2. Examine broad research priorities in relation to policies and strategic plans.

3. Review the regional distribution and orientation of the Canadian Forestry Service research programs and funding.

4. Review and advise on collaborative programs with forest management organizations and on the role of the Canadian Forestry Service in the context of other related research agencies.

5. Review and advise on technology transfer, i.e. the development and application of new and existing knowledge.

6. Review and advise on effective means of communication and information exchange between the Canadian Forestry Service and other regional, provincial and national research and research advisory bodies; 
7. Make recommendations to the Deputy Minister on any or all of the above, either on its own initiative or at the request of the Deputy Minister.

8. Prepare for consideration by the Canadian Council of Forest Ministers, an annual review and synthesis of the priorities and concerns of the senior provincial and territorial research advisory bodies.

\section{Membership}

Members shall be selected from the following groups:

Industry

5

Provinces

Universities

5 (B.C., Ont., \& Que. are permanent members)

$$
\underline{2}
$$

\section{Ex officio}

CPPA

CFS

The selection process shall pay due regard to the need for a wide range of experience and skills, regional balance and demonstrated leadership. Appointments will be made for periods of three years by the Deputy Minister in consultation with the three main participating groups. A Chairman and a Vice-Chairman will be selected by the Deputy Minister, the Vice-Chairman will not necessarily succeed to the Chairmanship.

\section{Method of Operation}

The Council shall meet no less than twice a year, at the call of the Chairman.

It will investigate and advise on specific topics chosen by the Council itself or at the request of the Deputy Minister.

The Council shall be empowered to establish subcommittees and make assignments to its members.

\section{Budget}

An annual budget will be provided by the Canadian Forestry Service to care for travel and related costs of meetings.

\section{Reporting Relationship} Minister.

The Council will make an annual report to the Deputy

DATE: 16 Nov., 1988

Original signed by J.S. Maini

Approved: Jean Claude Mercier

Deputy Minister (Forestry)

\section{Appendix IV \\ Action Report by Forestry Canada on Recommendations from FRACC 1987 Annual Report}

Itemized below are FRACC's recommendations from its 1987 report, along with the published CFS response to each and a note on the status of each.

Recommendation 1 - Council strongly recommends that the CFS initiate a program of periodic review of forestry sector research expenditures at the national level to provide a database for science policy decisions.

CFS Response - The CFS accepts the recommendation and will incorporate this requirement in operating procedures.

Action - The report by Dr. I.C.M. Place, "Forest Research in Canada 1979/80 and 1985/86," was slightly revised and distributed to FRACC in the summer of 1988. The main point of the revisions was to change the base for the reported expenditures to $1985 / 86$ dollars. The report has been printed and bound, and copies are available.

Dr. Kayll was commissioned in 1987 to develop a catalogue of forestry research expenditures. His microcomputerbased catalogue and report were submitted in April, 1988.

Recommendation 2 - Council further recommends that the CFS, in consultation with industries and provinces, address the question of adequacy of current levels of forestry research expenditures given increasing forest management programs.
CFS Response - The CFS will address the adequacy of resources as recommended, noting that the National Forum "Innovation and Technology: Science in the Forest Sector" was an initial step in this direction.

Action - Forestry Canada summarized the information in the Place report for presentation at the CCFM National Forum on Innovation and Technology: Science in the Forestry Sector. A national task force was established to develop an implementation plan to achieve the 13 recommendations agreed to at the forum. Mr. Mercier was a member of that task force.

The inadequacy of current levels of funding for Forestry Canada research programs was addressed in the O\&M review. The Treasury Board submission following this review resulted in enhanced federal forestry research funding.

Forestry Canada is working to ensure that the forest sector is properly recognized in a number of federal initiatives, such as the Centres of Excellence scheme. It should be noted that Forestry Canada is working with the Department of Industry, Science and Technology (DIST) on possible new initiatives relating to S\&T and innovation in the forest sector.

Recommendation 3 - Council welcomes and will undertake its expanded role; it strongly recommends that the CFS, in collaboration with provinces and territories, pursue the 
agreed initiative to create research advisory bodies and to improve synthesis and communication of research needs.

CFS Response - The CFS fully accepts this recommendation.

Action - Forestry Canada has been encouraging the formation of provincial research advisory bodies where they did not previously exist. In 1988, the Council of Forest Research was established in Quebec. A new MOU has been signed in Newfoundland which sets up a Committee conforming to the model. A new Committee has been established in Alberta under the auspices of existing legislation there. With the exception of B.C., there were already existing bodies in the other provinces that serve the purpose. Some of these may evolve in time to more closely correspond with the model recommended by FRACC. The previous MOU in B.C. was not renewed when it expired, and the Forest Research Council was reduced to three members. A consensus was developed at a recent workshop for a new advisory structure for forest research in B.C. This will see the establishment of a Forest Research Advisory Committee ("users"), along with a Committee of Research Agencies ("doers"). A reconstituted B.C. Forest Research Council is being considered.

Recommendation 4 - Council recommends that the strategic plan for research be revised periodically and be widely circulated to clients and collaborators in the forest sector.

CFS Response - The Honourable Gerald S. Merrithew has approved the CFS Strategic Plan for Research. The document "Focus on Research" will be periodically revised and widely circulated.

Action - "Focus on Research" has been widely distributed. Copies are still available for further distribution. Revision will be as and when necessary, but it is not anticipated that this will be any later than 1992.

Recommendation 5 - Council recommends that the CFS concentrate on communication with the public to increase awareness of the benefits of the appropriate use of pesticides.

CFS Response - The CFS accepts the recommendation while noting that this is a highly controversial subject requiring a high degree of objectivity.

Action - The Forest Pest Management Institute (FPMI) has prepared a video presentation entitled "Forest Protection - A Challenge for the Future" (26 minutes). This has been given wide exposure, with copies distributed around the world. Copies have been sent to schools of forestry and related resource management and environmental studies. It has been broadcast on community television stations. The presentation covers appropriate use of pesticides, environmental impact studies, and other testing programs. FPMI is trying to get a person-year for a Pest Management Information Officer who could follow up on this initiative.

Recommendation 6 - Council recommends that the CFS stress, in any negotiations regarding federal policies, the importance of a strong forest management research program by the Federal Government for the conservation and wise use of this publicly owned forest resource.

CFS Response - The CFS welcomes the recommendation.

Action - Elevation to departmental status has provided a focus for federal forestry activities and policies. Negotiations for a new series of federal-provincial agreements are stressing applied research and technology transfer activities.

Recommendation 7 - Council further recommends that the Ministry of State for Science and Technology review the reporting requirements of these new policies on science with a view to consolidation and reduction of paper burden.

CFS Response - The CFS agrees to initiate discussion with the Ministry of Science and Technology.

Action - The policies to which the report referred are being reassessed by both Forestry Canada and DIST in light of the reorganization of both agencies.

Recommendation 8 - Council recommends that the CFS review the issue of research and taxation as it affects the already low levels of of research expenditure in the forest sector.

\section{CFS Response - The CFS accepts the} recommendation.

Action - This recommendation was echoed by the CCFM Implementation Committee when it called for a full review of tax incentives. Forestry Canada is developing a proposal for a consultant to explore this issue and submit a status report early in the new fiscal year.

Recommendation 9 - Council encourages the CFS to develop a specific strategy for biotechnology research and recommends that the strategy emphasize the applications of biotechnology in forest management.

CFS Response - The CFS will develop a specific strategy for biotechnology research as recommended.

Action - The task force on biotechnology (Cheliak, Ennis, and White) has submitted a status report with recommendations. This was distributed to FRACC at the October, 1988 meeting. The task force report will form the basis of a strategic plan. FRACC members have recently received copies of "Biotechnology Network for the Forestry Industries." 